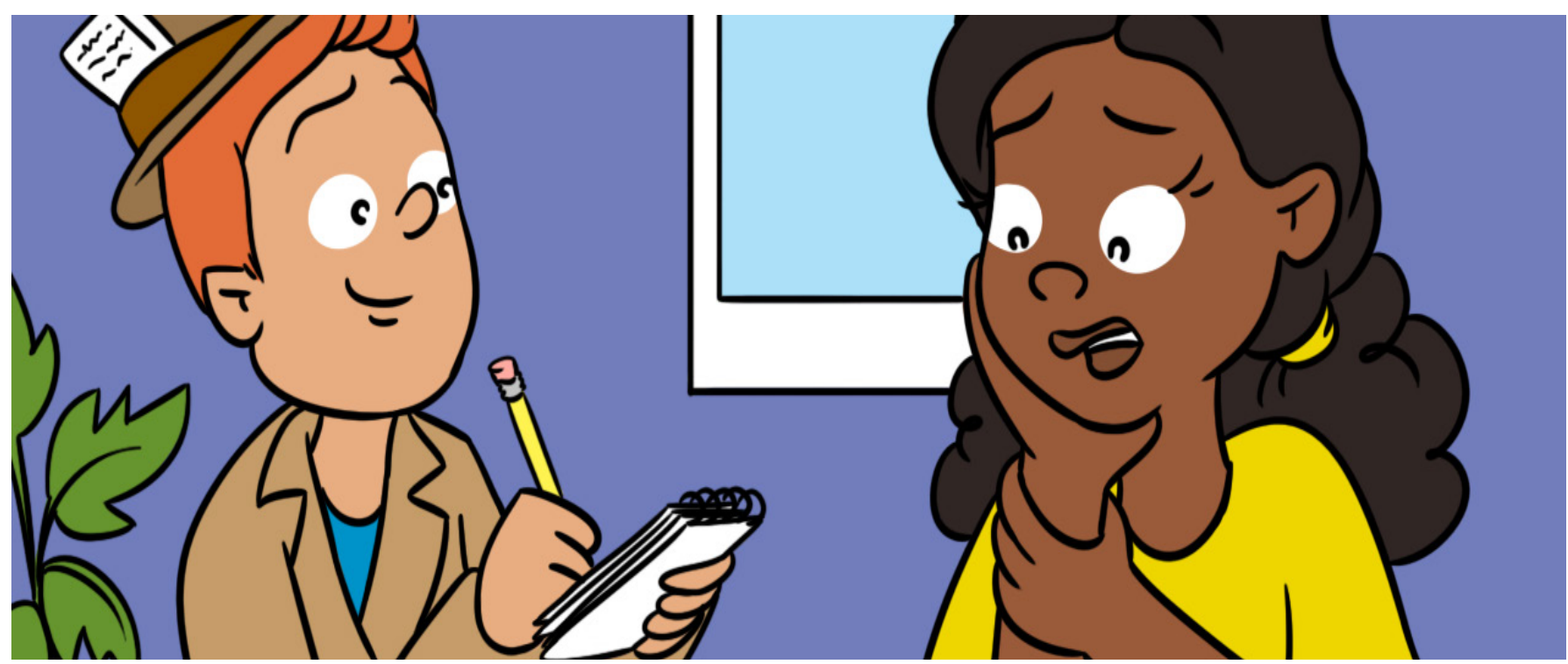

\title{
CRIME SOLVING: CAN YOU CORRECTLY REPORT WHAT YOU SAW?
}

\section{Rachel Bell', Ashleigh M. Maxcey ${ }^{2 *}$ and Elizabeth F. Loftus ${ }^{3}$}

${ }^{1}$ Department of Psychology, Vanderbilt University, Nashville, TN, United States, ${ }^{2}$ Department of Psychology, The Ohio State University, Columbus, $\mathrm{OH}$, United States, ${ }^{3}$ Department of Psychology and Social Behavior, University of California, Irvine, Irvine, CA, United States

\section{REVIEWED BY:

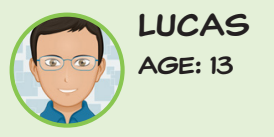 \\ MARTA \\ AGE: 14 \\ YAIZA \\ AGE: 15}

When someone has to report a crime, it is important that they describe the crime accurately. However, there can be many errors in their description because of the way memory works. There are three stages of memory that describe how we get information, keep it in memory, and then pull out that information to remember it. Unfortunately, because memory is not like a video camera that perfectly records our life events, errors can happen in all three memory stages. Memory can also be confused for other reasons, for example, when we try to identify a person of a different race. In this paper, we explain some of the errors that can happen across different stages of memory, and we suggest an activity you can do with your friends to see memory errors happen.

Do you see police officers around where you live? Being a police officer is a lot of hard work. Police officers help people, keep people safe, put criminals in prison, and sometimes they even put innocent people in prison. You may be thinking, "Do they really put innocent people in prison?" The answer is YES! Sometimes this can happen because people who try to help the police can accidently give the police the wrong information. 
EYEWITNESS

\section{ACCOUNT}

An eyewitness account is telling someone, like a police officer, exactly what you saw during a crime or other event. This report would include information such as what the thief looked like and what you saw him or her do.
If you are at the same place where a criminal is and you see them run off with a lady's purse, do you think you would be able to tell a police officer what the thief looked like? Reporting what you saw to the police is called an eyewitness account. Although accurately telling the officers what happened may seem easy, your eyewitness account can have mistakes. For example, in eyewitness accounts, people sometimes report that a criminal is taller than they actually are in real life [1]. Such error is a problem because police work can rely on eyewitness accounts to help solve some crimes. In order to understand why such eyewitness account errors happen, first we need to understand the stages of memory.

\section{STAGES OF MEMORY}

Encoding is the name for the first stage of memory, and it refers to getting information into memory. One factor that affects the information getting into memory is attention. For example, one study has shown that we often pay attention to the action or object instead of the details of the person [2]. To better understand this idea, imagine you were at the doctor's office and a nurse walked into your room and said, "You have to get a vaccine." She had a needle and syringe, used a germ-free wipe to clean your arm, and then she picked up the needle and said, "Relax." At this point, most of us would not be able to "relax!" When you do not like getting a vaccination, you might feel stressed because it is hard to focus on anything other than the needle or the pain of getting a vaccine.

In the above example, it is likely that you were only able to encode certain parts of the event. Did the nurse knock before entering the room? Did she wash her hands? Were her gloves blue or white? It is hard to remember! Our brains only encode some of the available information in the world, not all of it. As a result, you are usually not able to get the information you do not pay direct attention to into memory. In the vaccination example, you may have been too focused on the needle to remember much else about the situation. In this scenario, your memory of the event might be incomplete because of where you were placing your attention during the event. This type of encoding error is one of the reasons why eyewitness accounts are not always correct.

Storage is the second stage of memory and refers to holding on to the information we have in memory. One factor that impairs storage is the passage of time. This is because the longer we wait to give an eyewitness account after an event, the more likely we are to forget some of the details. In one study, people were shown a video of a robbery that had a weapon involved [3]. Half of the people had to describe what happened in the video right after they watched it, and the other half had to wait a week before describing what happened. The people who waited a week to describe the video had worse memory than those who were asked to describe the video immediately after watching it. 
Another factor that can affect memory at the storage stage is what we hear from other people around us. Our memory storage can be affected by extra information that we hear from others when they describe an event [4]. Going back to the doctor's office example, let us suppose that later that afternoon your brother tells you what he remembers from the appointment. Your brother might say, "I loved the dolphins and sea turtle painted on the wall." Because you heard your brother say this, even though you did not pay attention to the details of the wall, your brain may think that you remember paintings of dolphins and turtles on the wall. But, you learned this information after you arrived back home. If the information you hear from someone else is NOT accurate, that misinformation could make your memory of an event inaccurate.

Retrieval, the third stage of memory, is pulling out the information stored in your memory bank. The way questions are asked may affect your ability to accurately retrieve information and can change the memories you report. In a well-known study, subjects were shown a video of a car accident [5]. In one version of the study, the subjects were asked how fast the cars were going when they contacted each other; while in another version of the study, they were asked how fast the cars were going when they smashed into each other (Figure 1). Importantly, both groups of subjects saw the same video, so their memory of how fast the cars were actually going could not have been different. However, this change in the words used during questioning led people to report that the cars were going faster when they heard the word smashed compared with when they heard the word contacted. The way the questions were asked changed the eyewitness accounts of the car accident. If this happens during a real-life eyewitness account, something as simple as the words used during questioning could change the outcome of the case!

Another memory error that can happen during retrieval is confusing one memory with another memory. This was demonstrated in a study where people were shown a video of a robbery [6]. The video included an innocent person.

\section{LINEUP}

In a lineup, a number of people come in to a room and line up facing the same direction. The witness then reports which person, if any, they remember as the criminal from the scene of the crime.
After the video, the people were asked to identify the criminal in a lineup. The people who watched the video with the innocent person were shown a lineup that did not have the actual criminal in it. The lineup did include the innocent person who was in the video, alongside some other people who were not in the video. The correct response was to report that none of the people in the lineup were the criminal. But, some people reported that the innocent person was the criminal. This happened because the people remembered seeing the innocent person before, so they chose that person in the lineup because none of the other people in the lineup looked familiar. In this example, some people retrieved the wrong familiar face from their memory and claimed that familiar person was guilty. If this happens during an eyewitness account, an innocent person could be sent to jail just because they had the bad luck of being stored in the eyewitness' memory! 


\section{FIGURE 1}

This figure shows what happened in the car crash study by Loftus and Palmer [5]. In this experiment, people were shown a video of a car accident. Then, they were asked how fast the cars were going when they got into the accident. For example, the experimenter either asked how fast the cars were going when they smashed each other or contacted each other. Even though all the subjects saw the same video, the people who heard the word smashed reported a faster speed than the people who heard the word contacted. This is a really important finding, because it shows that the way a question is worded can change the person's reported memory.

\section{OTHER-RACE EFFECT}

People are often better at recognizing faces that match their own race. For example, an AfricanAmerican would be best at remembering the face of another AfricanAmerican

${ }^{1}$ We use the term race to refer to skin color, consistent with the original studies we described.
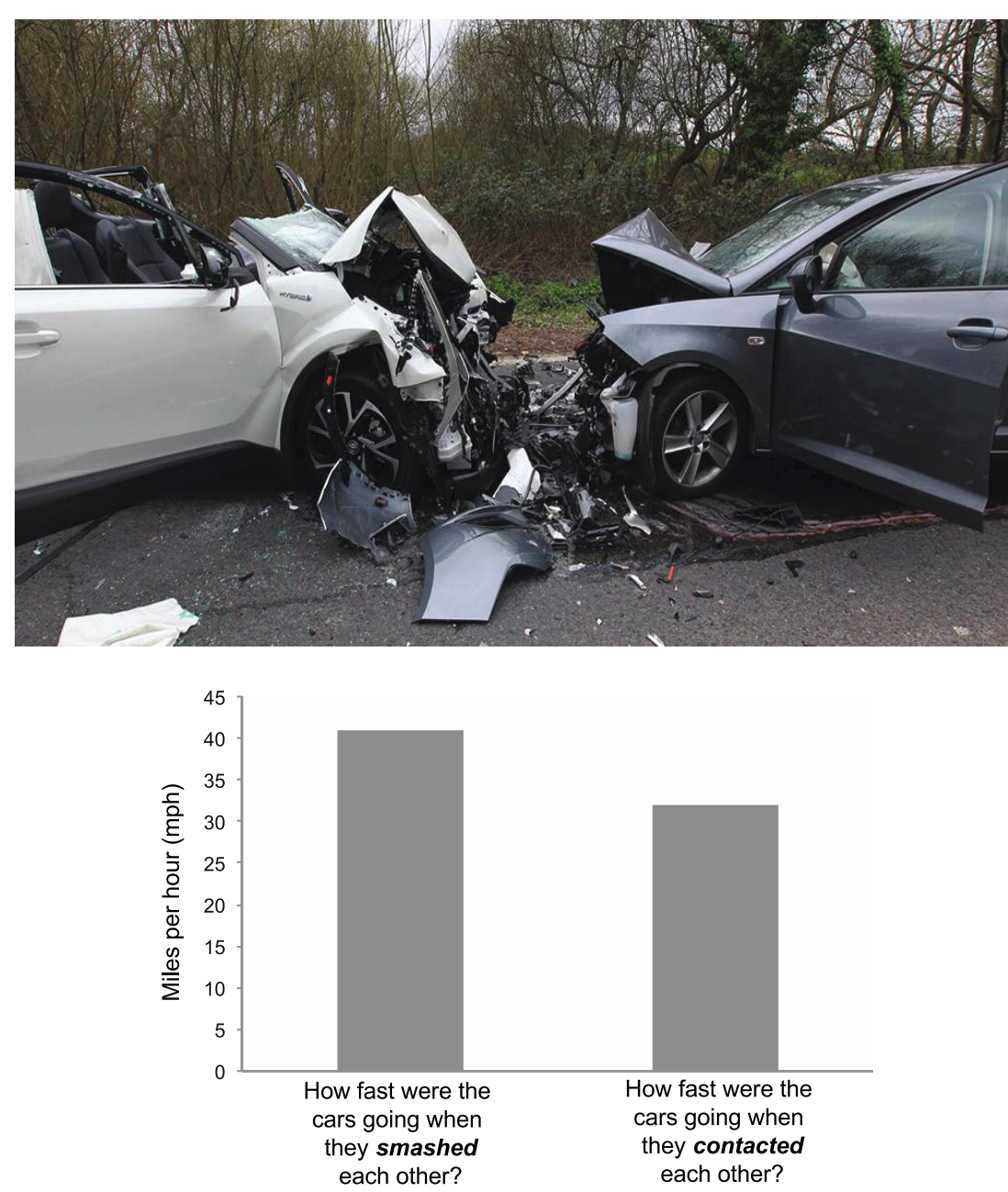

FIGURE 1

\section{THE OTHER-RACE EFFECT}

We have described how memory processes can have errors, leading to circumstances in which a police officer might arrest an innocent person. There are many other sources of memory error. For example, someone's skin color also provides a clue to whether his or her face will be memorable. This is called the other-race effect [7], and it means that eyewitnesses are better at identifying criminals if the eyewitness is the same race ${ }^{1}$ as the criminal. For example, a Caucasian person is better at recognizing Caucasian faces, and an African-American person is better at recognizing African-American faces. This means that police officers should be extra cautious in believing otherrace eyewitnesses.

\section{CONCLUSION}

We often wish that memory acted like a video camera, recording and saving files exactly as they occurred in real life. In this article, we explained some of 
the many factors that can affect the accuracy of memory. Often, we are not even aware when our memory is being damaged. The next time someone asks you how confident you are about something you remember, we hope you think of this article.

\section{ACTIVITY: GIVE AN EYEWITNESS ACCOUNT}

Do you want to demonstrate that memory is surprisingly inaccurate? Team up with your teacher and ask her to give your fellow students a surprise memory test. After you come back from music class, the teacher can ask the students in your class to write down everything the music teacher was wearing. For example, was the music teacher wearing a watch? What did it look like? Even though the students were looking at the music teacher for the last $45 \mathrm{~min}$ or so, most of the students will not be able to remember the details of the music teacher's outfit. This surprise memory test is a lot like giving an eyewitness account of a crime. Most people do not realize they are about to witness a crime and will need to remember everything they are about to see.

\section{REFERENCES}

1. Penrod, S., Loftus, E. F., and Winkler, J. 1982. The reliability of eyewitness testimony. A psychological perspective. In: Kerr NL, Bray RM editors. The Psychology of the Courtroom. New York: Academic Press. p. 119-68.

2. Steblay, N. M. 1992. A meta-analytic review of the weapon focus effect. Low and Human Behavior 16:413-24.

3. Lipton, J. P. 1977. On the psychology of eyewitness testimony. J. Appl. Psychol. 62:90. doi:10.1037/0021-9010.62.1.90

4. Shaw, J. S. III, Garven, S., and Wood, J. M. 1997. Co-witness information can have immediate effects on eyewitness memory reports. Law Hum. Behav. 21:503. doi:10.1023/A:1024875723399

5. Loftus, E. F., and Palmer, J. C. 1974. Reconstruction of automobile destruction: an example of the interaction between language and memory. J. Verbal Learn. Verbal Behav. 13:585-9. doi:10.1016/S0022-5371(74)80011-3

6. Ross, D. R., Ceci, S. J., Dunning, D., and Toglia, M. P. 1994. Unconscious transference and mistaken identity: when a witness misidentifies a familiar but innocent person. J. Appl. Psychol. 79:918. doi:10.1037/0021-9010.79.6.918

7. Meissner, C. A., and Brigham, J. C. 2001. Thirty years of investigating the own-race bias in memory for faces: a meta-analytic review. Psychol. Public Policy Law 7:3. doi:10.1037/1076-8971.7.1.3

SUBMITTED: 19 December 2017; ACCEPTED: 07 May 2018; PUBLISHED ONLINE: 28 May 2018.

EDITED BY: Marcel Ruiz-Mejias, Universidad Pompeu Fabra, Spain 
CITATION: Bell R, Maxcey AM and Loftus EF (2018) Crime Solving: Can You Correctly Report What You Saw? Front. Young Minds 6:21. doi:10.3389/frym.2018.00021

CONFLICT OF INTEREST STATEMENT: The authors declare that the research was conducted in the absence of any commercial or financial relationships that could be construed as a potential conflict of interest.

COPYRIGHT (C) 2018 Bell, Maxcey and Loftus. This is an open-access article distributed under the terms of the Creative Commons Attribution License (CC BY). The use, distribution or reproduction in other forums is permitted, provided the original author(s) and the copyright owner are credited and that the original publication in this journal is cited, in accordance with accepted academic practice. No use, distribution or reproduction is permitted which does not comply with these terms.

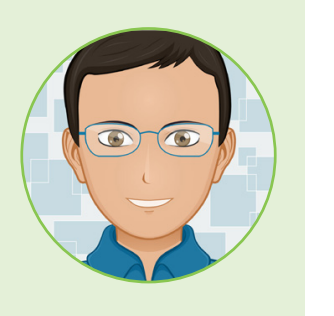

\section{REVIEWED BY}

\section{LUCAS, AGE: 13}

My name is Lucas and I am 13 years old. I live in Barcelona (Spain). My biggest hobbies are reading and sailing. I would love to go to Australia. I play the piano and the cello. At school, I love going to the lab and really enjoy science, especially biology and chemistry.

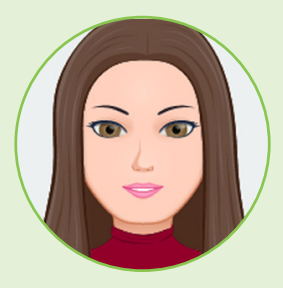

\section{MARTA, AGE: 14}

$\mathrm{Hi}$, I'm 14 years old, and I live in Barcelona, Catalonia. My hobby is playing basketball, which I started 7 years ago. I'm a 3rd E.S.O. student, and my favorite subject is Biology. In the future, I would like to become a geneticist or a science teacher. At school, I'm learning Spanish, Catalan, English, and German. I do not really enjoy them at all; however, I think they are quite useful. I love spending time with all my friends and family.

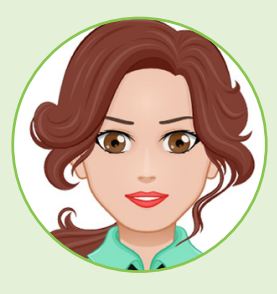

\section{YAIZA, AGE: 15}

I am 15 years old and I live in a small city called Ripollet next to Barcelona. One of my hobbies is reading, especially books. I also love practicing sport. At school, I study Spanish, English, Catalan, and German, which I have just started. I find science really interesting, and I love spending time with my family and my friends.

\section{AUTHORS}

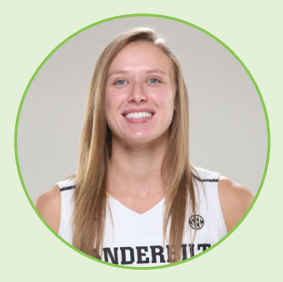

\section{RACHEL BELL}

Rachel Bell is a student-athlete at Vanderbilt University from Cumberland Furnace, TN, USA. She is in her senior year at Vanderbilt, double majoring in Psychology and Medicine Health and Society. Rachel played basketball for Vanderbilt and made the SEC All Academic Honor Roll three years in a row. She interned with the Vanderbilt Police Department for two summers where she learned about what police officers do on a day-to-day basis. Rachel has always been interested in criminal justice and plans to pursue a career in law enforcement and become an FBI agent. 


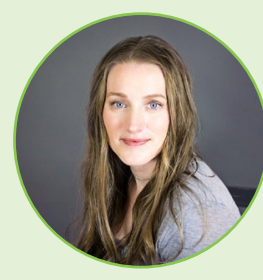

\section{ASHLEIGH M. MAXCEY}

Ashleigh Maxcey is a Visiting Associate Professor at Ohio State University in Columbus, $\mathrm{OH}$, USA and teaches over the summer at Vanderbilt University in Nashville, TN, USA. When she was an undergraduate at Purdue University, Dr. Maxcey was inspired to pursue her Ph.D. in cognitive psychology by the groundbreaking work of co-author Dr. Elizabeth Loftus. Now, Dr. Maxcey studies visual memory in her own laboratory at Ohio State and teaches courses on cognitive psychology, sensation and perception, neuroscience, research, and statistics. Dr. Maxcey loves traveling to present her research in cities around the United States like Minneapolis, Long Beach, Chicago, and Boston and internationally in interesting places such as Barcelona, Granada, Vancouver, and Amsterdam. Outside of work Dr. Maxcey enjoys cheering on her student athletes, like co-author Rachel Bell, with her husband and three children. *ammaxcey@gmail.com

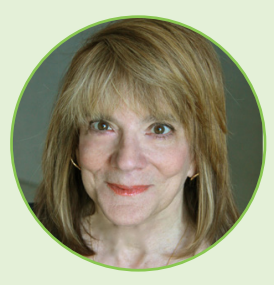

\section{ELIZABETH F. LOFTUS}

Elizabeth Loftus is a Distinguished Professor at the University of California, Irvine, CA, USA. She holds faculty positions in the Department of Psychology \& Social Behavior, the Department of Criminology, Law \& Society, and the School of Law. She received her Ph.D. in Psychology from Stanford University. Since then, she has published 22 books and over 500 scientific articles. Loftus's research has focused on the malleability of human memory. She has been recognized for her research with seven honorary doctorates and election to numerous prestigious societies, including the National Academy of Sciences. She is ex-president of the Association for Psychological Science, the Western Psychological Association, and the American Psychology-Law Society. Loftus's memory research has led to her being called as an expert witness or consultant in hundreds of cases. 